\title{
Irish law students and lawyers in late medieval England
}

Tn April 1421 the Irish parliament, meeting at Dublin, chose the archbishop of Armagh and Sir Christopher Preston as its messengers to convey to the king in England a long list of complaints. Among these was the following:

Also, your said lieges show that whereas they are ruled and governed by your laws as used in your realm of England, to learn which laws and to be informed therein your said lieges have sent to certain inns of court (hostelles de court) able men of good and gentle birth, your English subjects born in your said land, who have been received there from the time of the conquest of your said land until recently, when the governors and fellows of the said inns would not receive the said persons into the said inns, as is customary. Wherefore may it please your most gracious lordship to consider this and ordain due remedy thereof, that your laws may be perpetuated and not forgotten in your said land. ${ }^{1}$

This was, of course, something of an exaggeration. The Inns of Court certainly did not exist at the time of the English 'conquest' of Ireland; indeed, it is now fairly certain that the inns only came into existence around $1340 .^{2}$ It is also clear, however, that some kind of organised legal education was taking place in London before the inns were created, certainly as early as the 1270 s and quite possibly as early as 1260 , though definitely not in the twelfth century. ${ }^{3}$ We also know that as early as 1287 Irishmen (or at least one specific Irishman, Robert de St Michael) were crossing the channel 'causa addiscendi in Banco regis apud Westm' ', that is, specifically for the purpose of legal education at Westminster through attendance at the king's court there. ${ }^{4}$ Nor is this the only evidence to suggest that men born in Ireland were coming to England for legal education even before the creation of the inns.

${ }^{1}$ Stat. Ire., John-Hen. $V$, p. 575. This is also calendared in Rot. pat. Hib., pp 221-221b, no. 11.

${ }^{2} \mathrm{~J} . \mathrm{H}$. Baker, The third university of England: the Inns of Court and the commonlaw tradition (Selden Society, London, 1990), pp 9-12; Readings and moots at the Inns of Court in the fifteenth century, ii, ed. S. E. Thorne and J. H. Baker (Selden Society, vol. 105, London, 1990)), pp xxix-xxx.

${ }^{3}$ Paul Brand, The making of the common law (London, 1992), pp 61-4.

${ }^{4}$ Paul Brand, The origins of the English legal profession (Oxford, 1992), p. 207. For further details on Robert de St Michael see Colum Kenny, King's Inns and the kingdom of Ireland: the Irish 'Inn of Court', 1541-1800 (Dublin, 1992), pp 13-14. 
The Simon of Ireland (de Hibernia) who composed Latin verses (found in several legal manuscripts) on an appeal of robbery made by a child and quashed by Justice Bereford in Easter term $1305^{5}$ may well have been a law student from Ireland. ${ }^{6}$ When Roger of Ashbourne, a citizen of Dublin, received letters of protection and letters of attorney on moving to England for a two-year period in July 1290, he may well have been coming for a legal education, for he is almost certainly the Roger of Ashbourne who was a serjeant in Ireland between 1299 and $1307 . .^{7}$ Another early fourteenth-century serjeant who is known to have visited England (possibly for legal education) in $1302^{8}$ was Matthew Hanwood, who became a king's serjeant in $1310 .^{9}$ Two other possible law students of this period are John Gernun and Bartholomew Dardiz, both of whom appointed general attorneys to act for them in Ireland while they were in England in January 1327. ${ }^{10}$ Gernun is probably to be identified with the John Gernun who became a king's serjeant shortly afterwards and later became a justice; Dardiz with the man who was probably a professional lawyer and ended up as a justice of the Dublin bench in 1356. One other possible Irish law student in England in this early period is Roger de St Bride (de Sancta Brigida), one of the very few identifiable professional attorneys of the Dublin bench active in the court between 1299 and $1305 .^{11}$ By Michaelmas term 1312 he had become a serjeant. ${ }^{12} \mathrm{~A} 1313$ assize of novel disseisin heard at Cashel shows that he had returned from 'remote parts' in the fairly recent past; ${ }^{13}$ the 'remote parts' may perhaps have been Westminster (as seen from Cashel). He may have brought back with him to Ireland the magnificent book of law reports now in the British Library (Add. MS 35116), as well as the rather scrappier book of reports of which this is a fair copy (Harl. MS 25), both of which seem to have been in Ireland in the late middle ages. Both manuscripts have a marginal note in the sequence of dower and reasonable share cases (on $\mathrm{f}$. 91 $\mathrm{v}$ of Harl. 25 and copied on f. 132r of Add. 35116) reading: 'Nota bene pro

${ }^{5}$ A. J. Horwood (ed.), Year books, 33-35 Edward I (London, 1879), p. 97. The verses are also found after reports of the same case in B.L., Hargrave MS 375, f. 200r, in B.L., Harl. MS 572, f. 162v, and in Cambridge University Library, MS Mm. 1.30, f. 30v. He is also presumably the 'Irland' who made a brief Latin verse on a case heard in Easter term 1304 (B.L., Stowe MS 386, f. 209v).

${ }^{6}$ For a Simon of Ireland sued for a debt of $40 \mathrm{~s}$. in 1283 for money due for withdrawal from a trespass suit and who was sued in Buckinghamshire see P.R.O., CP 40/51, m. 99.

${ }^{7}$ Cal. doc. Ire., 1285-92, nos 718, 727; Brand, Making of the common law, p. 54. For evidence that he may already have been a serjeant in 1296 see Reg. St John, Dublin, pp $18-19$, no. 34 .

${ }^{8}$ Rot. pat. Hib., p. 7, no. 87.

${ }^{9} \mathrm{Brand}$, Making of the common law, p. 55.

${ }^{10}$ Cal. pat. rolls, $1324-7$, p. 347.

"Brand, Making of the common law, p. 46.

${ }^{12}$ There are two references in 1312-13 to the assignment of a share of damages to him (N.A.I., KB 1/1, mm 5,52), a common way in Ireland at this date of remunerating serjeants: see Brand, Making of the common law, p. 24.

${ }^{13}$ N.A.I., KB 1/1, m. 53 (and cf. m. 3d). 
Knocgraffon'. This must be a reference to Knockgraffon in County Tipperary, about seven miles south of Cashel, where a borough existed by $1274 .{ }^{14}$ Knockgraffon is a place where Roger de St Bride is known to have held land. ${ }^{15}$ The only original parts of these manuscripts not copied from earlier collections cover the years 1309-12, plausibly the time when Roger was at Westminster gaining the legal expertise which was to turn him from a professional attorney into a professional serjeant.

Only in the case of Robert de St Michael can we be absolutely sure that a particular individual during this early period came from Ireland to England for the purposes of legal education, but there is at least a possibility, even a probability, that some, if not all, of the other individuals mentioned also visited England for this same purpose. This does not necessarily mean that no kind of legal education was available in Ireland. As I have shown elsewhere, both the English pleading manual Novae narrationes and the English instructional treatise Natura brevium were altered or adapted in the late thirteenth or early fourteenth centuries with a specifically Irish audience in mind, and while it is possible that both works may only ever have existed as written compositions, it is perhaps as likely that they record the content of actual oral instruction given in Ireland. ${ }^{16}$ But if such instruction was available in Ireland, it looks as though Westminster may early have established a reputation as the centre for the more advanced study of the common law for lawyers intending to practise in Ireland as well as in England, a reputation which already existed by the time the Inns of Court were themselves created. It is difficult to believe that there was any kind of direct compulsion on Irish lawyers to study in England at this early stage; but if it was only at Westminster that the more advanced instruction in the common law was given, it may soon have become necessary for those who wished to practise law at a higher level in the colony to travel to England to receive legal instruction.

There is rather better evidence for Irishmen coming to England for the purposes of legal education during the eight decades between the date of the probable foundation of at least some of the Inns of Court in the early 1340 s and the 1421 petition.

In 1344 two Irish apprentices of the Westminster bench (law students), Richard of Cardiff and John de Barri, for example, were indicted with an English colleague (John of Worcester) as being common evildoers who lay in wait in London at night to rob passers-by of their belts and purses. We can

\footnotetext{
${ }^{14}$ Geoffrey Martin, 'Plantation boroughs in medieval Ireland, with a handlist of boroughs to c. $1500^{\prime}$ in David Harkness and Mary O'Dowd (eds), The town in Ireland: Historical Studies XIII (Belfast, 1981), pp 44-5.

${ }^{15}$ Brand, Making of the common law, p. 46.

${ }^{16}$ Ibid., pp 31-2, 462, 464.
} 
assume that they had at least started out as genuine law students and may suppose that they had adopted this method of gaining income in the absence of an adequate student loan scheme. ${ }^{17} \mathrm{~A}$ more distinguished compatriot who was in England in the following decade was John Keppok (or Cappoge), who gave his name to one of the 'moot cases' that were a longlived feature of the educational system of the Inns of Court. He is probably to be identified with the John Keppok who was in England between 1352 and 1356 and who on his return to Ireland became a serjeant and then a royal justice. ${ }^{18}$

A number of other future king's serjeants and royal justices can also be shown from their appointment of attorneys to act for them in Ireland during absence in England to have spent some time in England in the midfourteenth century: Richard Plunket for one year in $1342^{19}$ and again for five years between 1349 and $1354,{ }^{20}$ Robert of Preston for an unknown period beginning in 1346/7; John Tyrell for a total of six years between 1354 and $1359 .{ }^{22}$ It seems likely that they were in England for educational purposes, though this cannot be proved. Other future royal serjeants and justices can be traced in England during the second half of the fourteenth century because they also received appointments from compatriots to act as their general attorneys while they were in England. It is from such appointments that we know that Richard White of Clongill (a serjeant in Ireland and later a justice) was in England in $1352,{ }^{23}$ and Peter Rowe (later a king's serjeant and chief justice of the justiciar's court) in 1377,1378 and $1379 .{ }^{24}$ Again it seems likely, though not provable, that they were in England for educational purposes. It is also from such appointments that we know that John fitz Adam (who became chief justice of the Dublin bench in 1396) paid a first

${ }^{17} \mathrm{~A} . \mathrm{H}$. Thomas (ed.), Calendar of the plea and memoranda rolls of the city of London, 1323-64 (Cambridge, 1926), p. 213.

${ }^{18}$ Thorne \& Baker (eds), Readings \& moots, ii, pp xliii-xliv.

${ }^{19}$ Cal. pat. rolls, $1340-43$, p. 570.

${ }^{20}$ Ibid., $1348-50$, p. 254 ; ibid., $1350-54$, p. 244 ; ibid., $1354-8$, p. 29 . He may have made a home visit to Ireland in 1352 (ibid., 1350-54,p. 356). Relative seniority within the profession may be indicated by his appearance in 1352 and 1353 among those commissioned to inquire on those breaking into parks and closes of the queen (though this might be a namesake) (ibid., 1350-54, pp 287, 288, 448-9). He became king's serjeant in 1358 and was later a royal justice in Ireland.

${ }^{21}$ Rot. pat. Hib., p. 50, no. 89 . He became king's serjeant in 1348, and in 1358 chief justice of the Dublin bench.

${ }^{22}$ Cal. pat. rolls, 1354-8, pp 97, 275, 535; ibid., 1358-61, p. 63 . In 1366 he became king's serjeant and was later appointed a puisne justice of the justiciar's court, finally becoming chief justice of the Dublin bench.

${ }^{23}$ Ibid., 1350-54,p. 244 (with Richard Plunket). By 1354 he was back in Ireland and acting as Richard Plunket's general attorney there (ibid., 1354-8, p. 29). In November 1352 he was licensed (with Plunket and one other) to buy wheat in Ireland and bring it to England or Wales for profit (ibid., 1350-54, p. 356). He was paid a fee by Archbishop Sweteman as a serjeant and later was a justice and chief justice of the justiciar's court.

${ }^{24}$ Ibid., 1377-81, pp 79, 82, 269, 274, 327, 393. In 1381 he became a king's serjeant, and he served as chief justice of the justiciar's court in 1382 and again in 1391-3. 
visit to England between 1379 and 1383 or later, ${ }^{25}$ as well as the second visit in and after 1392 for which he received a licence from the Irish chancery (necessary after the 1380 Statute of Absentees) for his absence in England 'causa erudicionis in jure'. ${ }^{26}$ It is conceivable, however, that his return visit to England was not to learn but to teach law, for he may have been taking his turn as a 'reader', lecturing on the statutes at his Inn of Court. ${ }^{27}$ The same may also have been true of John Bermingham (who in 1400 became king's serjeant in Ireland and in 1402 a justice of the justiciar's court), who likewise spent an initial period of at least three years in England between 1381 and $1384^{2 x}$ and who also received a licence from the Irish chancery in 1392 to absent himself 'causa erudicionis in jure'. ${ }^{29}$ Similar licences show that William de Tynbegh (a future king's attorney, chief baron of the exchequer, chief justice of the Dublin bench and treasurer of Ireland) travelled to England 'causa erudicionis in jure' in $1392{ }^{30}$ that Richard de Verdun (otherwise unknown) was given permission to stay for one year in England in 1402 'causa erudicionis legis communis'; ${ }^{31}$ that Richard Golding was given licence to travel to England 'ad discendum leges apud London' ' and stay there for two years also in $1402 ;^{32}$ and that Richard Bagot (perhaps the man who was an oyer and terminer commissioner in County Louth in 1420 and a justice of the peace in the same county in 1421 and also described as a narrator in a deed of 1425) had permission 'se absentandi per triennium ad studendum in Anglia' ${ }^{33}$ Similar licences were also available from the

\footnotetext{
${ }^{25}$ Ibid., pp 398 (jointly with the future Irish serjeant of the Westminster bench, William Skrene), 600 (jointly with John Bermingham, a future king's serjeant and royal justice), 614. Even after this first visit he was sufficiently senior within the profession in Ireland to be commissioned in September 1386 with Peter Rowe, the king's serjeant, to inquire as to the goods and chattels of John Penros, late justice of the justiciar's court, who had fled from Ireland, and as to extortions committed by him (Rot. pat. Hib., p. 136, no. 183) and to be appointed in July 1389 as justice for an assize of novel disseisin with Peter Rowe and Richard Cruys (ibid., p. 146, no. 182).

${ }^{26}$ Ibid., p. 149b, no. 101.

${ }^{27}$ For evidence that readings on the statutes go back to at least the reign of Richard II and quite possibly the second quarter of the fourteenth century see Baker, Third university, p. 6; Thorne \& Baker (eds), Readings \& moots, ii, pp xxiii-xxv.

${ }^{28}$ Cal. pat. rolls, $1377-81$, p. $600 ; 1381-5$, p. 227 . It was after this first visit that he is to be found acting as a serjeant for All Hallows outside Dublin some time before March 1391 (Reg. All Hallows, Dublin, pp 89-90) and as the king's serjeant (in Counties Dublin, Meath, Louth and Carlow) from 24 September 1388 onwards.

${ }^{29}$ Rot. pat. Hib., p. 149 b, no. 100. On 12 October 1392 he also appointed general attorneys to act for him while in England (ibid., p. 148b, nos 67-8).

${ }^{30}$ Ibid., p. 149 b, no. 99.

${ }^{31}$ Ibid., p. 163 , no. 109.

${ }^{32}$ Ibid., p. 164 , no. 152 . He received a further licence of absence (with no cause stated) in March 1414 (ibid., p. 202b, no. 32). He is perhaps the 'Goldyng' who occurs as a 'yeoman' in a fragment of an early fifteenth-century steward's account from an unidentified Inn of Court in Cambridge University Library, Additional MS 8936 (vellum guard between ff 6 and 7) (I owe this reference to Professor J. H. Baker).

${ }^{33}$ Rot. pat. Hib., pp 176, no. 148;217, no. 9; $221 \mathrm{~b}$, no. 112; Dowdall deeds, no. 416.
} 
English chancery, for example those giving Michael Braylys permission in 1401 to live in England for three years 'to learn the law of the realm' ${ }^{34}$ and Henry Clakestoun permission in 1405 to live in England for eight years 'while learning the law'35 (though he seems to have returned to Ireland before the end of this period, since in 1409 he was appointed as one of the justices in County Kildare). ${ }^{36}$

It is also possible to identify at least one legal manuscript which was probably taken back to Ireland by an Irish law student during this period. This is a register of writs probably written in 1384 and now in Harvard Law Library (Harvard Law School MS 34). ${ }^{37}$ There is nothing about the register that is anything other than English. It is, however, preceded by a calendar into which has been added not only the feast-day of St Patrick, bishop and confessor and apostle of Ireland, but also a series of death notices of which the earliest is for Christopher Talbot, who died in September 1409 (and who is possibly, but not certainly, Irish-born), ${ }^{38}$ and which also include the indubitably Irish-born William Chevir, second justice of the justiciar's court and his wife Alice Trevers (both of whom died in 1447) and Eleanor, daughter of Robert Holywood and widow of Richard Bermyngham, who died the same year. It seems likely that this manuscript was in Ireland by the early fifteenth century (if not before) and was taken there by an Irish law student (perhaps by the Christopher Talbot whose death it records).

\section{III}

The 1421 complaint is the first hint we have that there was any problem about the admission of Irish students to the Inns of Court. The problem seems, however, to have persisted or at least to have recurred on a number of subsequent occasions during the course of the fifteenth century. At another parliament held at Dublin in 1428 the English-born chief justice of

\footnotetext{
${ }^{34}$ Cal. close rolls, 1399-1401, pp 446, 447. But he had been in England earlier, for in September 1397 he was appointed a general attorney there for two years (Cal. pat. rolls, 1396-9,p. 187). In 1401 he was a sufficiently senior figure to be appointed as one of the guardians ad litem to act in England for the king's son, Thomas of Lancaster, chief governor of Ireland (ibid., 1401-3, p. 1).

${ }^{35} \mathrm{Cal}$. pat. rolls, $1401-5$, p. 480 . Evidence to suggest that he may already have embarked on a professional career in the law is provided by the letters patent of 1399 appointing him the general attorney in Ireland of a man living in England (ibid., 1399-1401, p. 145) and the renewal of these letters for a further year in 1403 (ibid., 1401-5, p. 228).

${ }^{36}$ Rot. pat. Hib., p. 193b, no. 170 . In 1415 he was named to a general oyer and terminer commission for Dublin, Meath, Louth and Drogheda immediately after the treasurer of Ireland and the chief justice of the Dublin bench (ibid., p. 211, no. 38).

${ }^{37}$ J. H. Baker, English legal manuscripts in the United States of Amercia, i: Medieval and Renaissance (Selden Society, London, 1985), p. 22.

${ }^{38} \mathrm{He}$ is possibly the son and heir of the Thomas Talbot who held land valued at $£ 20$ in Dublin, Meath and Kildare, whose wardship was granted to Thomas Flemming in 1400 (Cal. pat. rolls, 1399-1401, p. 227).
} 
the justiciar's court, Henry Fortescue, and Thomas Strange were appointed as messengers to take a further set of complaints to the king and council in England, including one containing a specific request:

Forasmuch as your laws of this land in every of your courts at all times have been used both in pleading and judgement giving after your laws used in England and the learned men here your said laws learnt in Inns of Court in your Realm of England unto now late that they been refused to be had in Inns of Court contrary to that that hath be used afore this time ... ordinance be made there that your liege people of this land that come thither for her [their] said learning may be received into Inns of Court as they have been of old time so that your laws in this land may be continued forth; Considering that else, when these that now been here learnt being dead, there shall be none in this land that shall canne [ken] your laws lasse [unless] that it be learnt there - the which will be a great disprofit for you and great hindering for us your poor lieges. ${ }^{39}$

On neither of these occasions do we know the response of the English government to the complaints, but in 1442 it is recorded that the chancellor of Ireland, Thomas Chace, was rewarded with $£ 20$ for bringing a 'full and effectual response' (plenum et effectuale responsum) to a further complaint about the English born in Ireland not being admitted to the Inns of Court on the same terms as the English born in England. ${ }^{40}$

One might be tempted to infer from this that the English born in Ireland were wholly excluded from the Inns of Court between 1421 and 1442 . Such a deduction would, however, be wrong. It is possible to trace in the records of Lincoln's Inn (which survive from 1422 onwards) a series of individuals whose surnames strongly suggest that they are from Ireland: the Somerton who was spending a second Christmas vacation there in 1422 (probably Edward Somerton, the future king's serjeant (1438-47) and justice of the justiciar's court (1447)); ${ }^{41}$ the Dartas or Dartoys present for his first Christmas in $1422{ }^{42}$ the Preston present for his first Christmas in $1433,{ }^{43}$ and surely the Roche and Thomas Bathe, both present for their first Christmas vacations in $1433 .{ }^{44}$ In addition, there is the evidence of a decision made by Lincoln's Inn in 1437 that no person born in Ireland should in future be admitted as a 'fellow' of the society. This carries with it a pendant: that anyone born in Ireland who had already been admitted was to be expelled notwithstanding their prior admission. ${ }^{45}$ This certainly suggests that there were Irish 'fellows' of the inn in 1437. Nor does it mean that there

${ }^{39}$ Facs nat. MSS Ire, iii, app. vi and plate xxxix. The entry is also calendared in Rot. pat. Hib., pp 247-8, no. 9.

${ }^{40}$ Rot. pat. Hib., p. 263b, no. 21.

${ }^{41}$ The records of the Honorable Society of Lincoln's Inn: Admissions, A.D. 1420-1893 (2 vols, London, 1896), i, 4. Professor J. H. Baker, however, has pointed out to me that this may have been the Thomas Somerton who was sued for arrears of dues owed at Lincoln's Inn in 1448.

${ }^{42}$ Ibid.

${ }^{43}$ Ibid., p. 7.

${ }^{44}$ Ibid.

${ }^{45}$ The records of the Honorable Society of Lincoln's Inn: Black Books, A.D. 1422-1914 (5 vols, London, 1897-1968), i, 8. 
could not be Irish students at Lincoln's Inn even after 1437, for being admitted as a 'fellow' of the inn seems only to have come after an initial period of attendance as a student ('clerk') at learning vacations at the inn. ${ }^{46}$

Nor do we know for certain just why the Inns of Court took measures during this period against the attendance of Irish law students. They may represent an over-enthusiastic enforcement of measures intended to ensure that the English of Ireland remained at home and were available for the defence of the colony, though the timing of the complaints does not fit well with the best-known governmental measures against the Anglo-Irish resident in England (in 1413, 1430 and 1439) ${ }^{47}$ nor with the fact that the measures of 1430 and 1439 specifically exempted 'men of law', a category which must surely have been intended to cover students at the Inns of Court. ${ }^{48}$ It is possible (as Colum Kenny has suggested) that 'professional exclusivity and even sheer chauvinism may also have been motivating factors', ${ }^{49}$ though since most of the Irish-born students were clearly intending to practise back in Ireland and not in England, professional exclusivity (though not chauvinism) may be less convincing as an explanation than it might look at first sight. One other possibility which merits serious consideration is that the Anglo-Irish were felt (as a group) to be delinquent in their responsibilities to their inns. The learning exercises in the Inns of Court which helped to educate each new generation of law students seem to have depended on the regular, active participation of recently graduated 'fellows' of the inns. It may be that the AngloIrish, having taken advantage of the system in being educated as students, were too eager (albeit for good career and financial reasons) to return to Ireland to play their proper part in the education of the next generation of law students, and that it was this which generated the resentment which led to them being barred altogether from the inns.

Lincoln's Inn did not in practice maintain even its ban on the Irish becoming 'fellows' of the inn, and by the 1450 s seems to have wholly changed its attitude to their membership. In $1452 / 3$ one Plunket (alias Blonket) from Ireland (perhaps the future chief justice Thomas Plunket) was admitted to the society, 'any act or ordinance to the contrary notwithstanding', and this was specifically said to be because he had brought many 'fellows' to the society. ${ }^{50}$ In 1455 a member of the Bathe family was admitted to Lincoln's Inn, and this was specifically on condition that he bring two other fellows of good conversation into the society. ${ }^{51} \mathrm{He}$ was also pardoned attendance at future learning vacations in return for introducing these two fellows and providing glass for the east end of the hall of the inn. ${ }^{52}$ Another member of the same Anglo-Irish family (John Bathe junior) was admitted to the

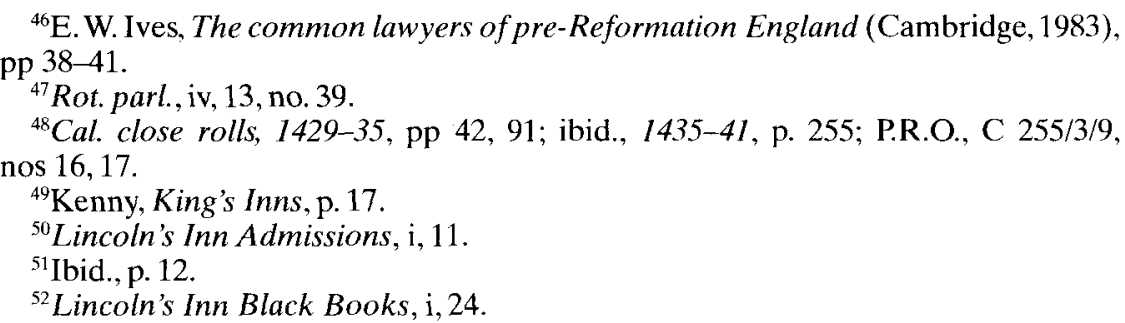


society in August 1457. He gave the society a gradual for his admission, but was required to attend all the learning vacations. ${ }^{53}$ The 1450 s provided one other instance of someone specifically described as from Ireland being admitted a fellow: Thomas Dowdale (in 1459). This is probably the man who became a king's serjeant in 1462 and as a countour was granted the office of keeper of the rolls for life in 1471/2. ${ }^{54}$ At least two other men from Ireland were admitted during the same decade as fellows of Lincoln's Inn, though not specifically identified as such in the inn's records: one Lynch, admitted in $1452,{ }^{55}$ and Peter Travers, admitted in $1456 .{ }^{56}$

Although the Black Books of Lincoln's Inn provide no evidence of a specific decision to that effect, it is noticeable that no one from Ireland and no one with an obviously Irish name is to be found among those admitted to the fellowship of the inn during the 1460 s or first half of the 1470 s, and it seems likely that there was another temporary ban on Irish admissions during this period. The flow of Irish 'fellows' seems only to resume with the admission of John Devereux in 1477 and Patrick Bermingham in $1478^{57}$ followed in 1482 by (John?) Wyse, in 1485 by (William?) Darcy and (Richard?) Nangle and probably Robert Preston (though he is not specifically identified as from Ireland), and in 1486 by John Ormond. ${ }^{58}$ It is not clear whether there was as yet even in 1485 an Irish quota at Lincoln's Inn. There was certainly one by 1542 , which allowed only four Irish-born students at the inn at any one time, ${ }^{59}$ and the residential segregation of these four Irish students in the chamber called the 'Dovehouse' (enforced by an order of 1556$)^{6(1)}$ may already have existed in $1522-3$, when the pensioner of the inn accounted for fees for admission to the Dovehouse from students named Kyltall, Barnwell and Sedgrave. ${ }^{61}$

The published Irish statute rolls allow us to add a few more names. These may well be of Irish law students at the other three inns, whose fifteenthcentury records do not survive. An act of resumption of 1460 exempted from its effects Barnaby and Christopher Barnwall, 'who were at court in the city of London to hear the law' (esteant en le court al citee de London pur oyer la ley).$^{62}$ In 1471/2 Christopher Preston and Thomas Cusake (the latter presumably the man who became attorney general in 1480 and chief justice of the justiciar's court in 1490) were licensed to export corn from Ireland since they were intending to go to England to 'study and hear the law' (illeosques

${ }^{53}$ Ibid.; Lincoln's Inn Admissions, i, 13.

${ }^{54}$ Lincoln's Inn Admissions, $\mathrm{i}, 14$.

${ }^{55}$ Ibid., p. 11.

${ }^{56}$ Ibid., p. 13.

${ }^{57}$ Ibid., p. 21; Lincoln's Inn Black Books, i, 64. Bermingham seems still to have been there in 1486, when he was put out of commons for various offences but paid a fine for readmission (Lincoln's Inn Black Books, i, 84).

${ }^{58}$ Lincoln's Inn Admissions, i, 22-4; Lincoln's Inn Black Books, i, 64, 82-3.

${ }^{54}$ Lincoln's Inn Black Books, i, 261.

(n)Ibid., p. 315.

${ }^{61}$ Ibid., p. 205.

${ }^{62}$ Stat. Ire., Hen. VI, p. 725. This may well be the Barnaby Barnwall who in 1461 became a justice of the justiciar's court. 
de estudier et oier la ley) or 'to labour, study and ground ... at London in the king's law' (laborer, estudier et ... founder . . . en la ley du Roy). Robert of Exeter was licensed to absent himself from Ireland for six years 'at London or the court to hear the law' (a Loundres ou Courte . . pur oier la ley). ${ }^{63}$ In 1479/80 Walter Eustace of County Dublin managed to gain a temporary remission of tax on his land on the grounds that he was obliged to be at London 'at court' and would not be able to continue there without it. This arrangement was to last only for as long as he remained in England at court 'to hear the law' (si longement come le dit Water demurra en Engletere al Courte de oier la ley). ${ }^{64}$ Almost certainly, however, these names constitute only a small proportion of the total number of Irish law students in England in the fifteenth century whose names and identities are no longer recoverable.

\section{IV}

The available evidence of Irish lawyers acting in a professional capacity in England is even more fragmentary, though it should be possible with research to uncover more of the story. There is certainly evidence from the second half of the thirteenth century and early fourteenth century to show Irish lawyers going to England on the business of their Irish clients. This may have been the reason why John of Athy was in England in $1267 .{ }^{65}$ It was certainly the reason why his son William was there in 1279 , and probably why he was there again in $1282 .{ }^{66}$ It is almost certainly for the same reason that Roger of Ashbourne travelled to England in $1305 .^{67}$ The practice is likely to have continued in the fourteenth century and perhaps in the fifteenth century, though I have found no evidence to prove it.

Other Irish lawyers certainly travelled to England on their own business. The former Dublin bench justice, John of Grantchester, is known to have gone to England in 1329-30 to secure a pardon of the fine he had agreed to pay for the maintenance of a litigant and other offences and to ensure his

${ }^{63}$ Stat. Ire., $1-12$ Edw. IV, pp 791, 793-5.

${ }^{64}$ Stat. Ire., $12-22$ Edw. IV, pp 811-3.

${ }^{65}$ On this occasion two men acknowledged owing a debt to him in the English court of king's bench which was payable in London (P.R.O., KB 26/181, m. 11). I take it that he is the man found suing for the king in the 1260 Cork eyre (N.A.I., RC 7/1, pp 248, 260) and in the Dublin bench or Dublin eyre of 1261 (ibid., pp 323,327) and who by $c .1270$ had become deputy seneschal of Kildare (P.R.I. rep. D.K. 36, p. 23).

${ }^{66}$ In 1278 William was appointed the attorney of the abbot of Dunbrody for a case in the English court of king's bench (Cal. doc. Ire., 1252-84, no. 1448) and in 1279 was again appointed by the abbot for another suit there (though his name is here recorded as John of Athy) (ibid., no. 1541). In 1282 he was given letters of protection while in England as a king's serjeant (Cal. pat. rolls, 1281-92, p. 16).

${ }^{67}$ N.A.I., RC 7/10, p. 585. This was probably on the business of the city of Dublin for which he had originally agreed a payment of 20 marks but eventually demanded 50 marks instead (Cal. justic. rolls Ire., 1305-7, pp 315-16). 
own reinstatement as a justice of the Dublin bench. ${ }^{68} \mathrm{He}$ apparently returned in 1331 to prosecute a writ of error in the English court of king's bench to reverse proceedings that had involved him in the Irish justiciar's court (in Hilary term 1331) and remained to prosecute a second writ of error in Michaelmas term to reverse the judgement which had led to his removal from the Dublin bench. ${ }^{69}$ In 1342 another former royal justice (who had earlier been a professional serjeant in Ireland), Simon fitz Richard, found sureties to appear before king and council in England, went to England, and was again bailed in England after he had been arrested there. $^{70}$

Although Irish lawyers came to England for their education, and most were from families whose origins were ultimately English, it was almost unknown for them to stay in England and pursue a legal career in that country. Almost, but not quite. The one indubitable example of an Irish law student who did make a successful transition to being an English lawyer is William Skrene. " Although Skrene's surname was derived from Skreen in County Meath, he seems to have come from a family that lived in Dundalk. He first travelled to England in or before 1378. In that year he can be found appointing general attorneys to act on his behalf in Ireland, and in the following year he was appointed (with another Irish lawyer, John fitz Adam) as the general attorney in England of Thomas Nugent, then resident in Ireland. In 1380 (after the Statute of Absentees was passed) he was excused non-residence in Ireland for the following two years on the grounds that he was an apprentice of the law and had been engaged in the study of law in England for some time before the enactment of the statute and ever since. Thus far he looks very much like other Irish law students whose residence in England was only temporary. His Irish connexions were still apparent in 1385 , when he was to be found (with three other Irishmen) acting as surety for an Irish religious house in taking a lease of the alien religious house of Fore. In this he is still called William Skrene 'of Dundalk'. In 1388 he appointed attorneys to act for him in Ireland while he stayed on in England. But in 1386 he was appointed to his first English quasi-judicial commission (inquiring into waste allegedly committed in the Kent manor of Erith), and in 1388 he served as a member of a similar commission (into waste allegedly committed in the manors of Lewisham and Greenwich). By 1390 Skrene was not only appointed to commissions of sewers for the bank of the Thames between Woolwich and Greenwich, and the Lea between Stepney and Bromley, but was also appearing among groups of feoffees for land in

\footnotetext{
${ }^{6 \times}$ Cal. pat. rolls, $1327-30$, pp 471-2, 475. He did not return to Ireland until September 1330 (ibid., 1330-34, p. 4).

${ }^{69}$ P.R.O., KB 27/283, m. 155 et seq.; ibid., KB 27/286, m. 128. That he was in England in person for these proceedings is shown by the letters of attorney he obtained when returning to Ireland from England in December 1331 (Cal.pat. rolls, 1330-34, p. 227).

${ }^{7 /}$ Cal. close rolls, $1341-3$, pp 492, 554-5.

${ }^{71}$ For a fuller discussion of Skrene and his career and for full references for what follows see Paul Brand, 'An Irishman in Westminster Hall: William Skrene of Dundalk, king's serjeant at law (c. $1358-c .1420$ )' in Ir. Jurist, n.s., xxxi (1996), pp $255-65$.
} 
Suffolk and for property in London and Norfolk; he also acquired a Suffolk manor for himself. In 1392, 1393 and 1394 he acted as counsel in the city courts in London and was appointed to sit on further commissions of sewers in Surrey and Kent. It therefore comes as no great surprise to find Skrene being licensed in August 1394 at the request of Bishop Braybrooke of London to stay in England for life, notwithstanding his Irish birth, nor to find him becoming a serjeant of the Westminster bench in 1396 and holding the office of king's serjeant from 1408 to 1414 . This does not mean that he never returned to Ireland - indeed he did, accompanying Richard II to Ireland in 1394-5 and becoming (albeit briefly) chief baron of the Irish exchequer; but he was back in England by the end of 1395, and his promotion to serjeant of the Westminster bench soon followed.

Thereafter Skrene's career was very much that of a successful English serjeant at law. He was appointed to judicial commissions (assize commissions, jail delivery commissions, oyer and terminer commissions and commissions of the peace), and he acquired lands in Cambridgeshire, Essex, Hertfordshire and Kent and in the parish of St Mary le Strand and other parishes close to London. He died (apparently in England) between 1419 and 1421, having firmly established his family in England. Skrene was commemorated in the window of the hall of Clifford's Inn as having been called to the degree of serjeant at law from that inn. Clifford's Inn was later regarded as an inn of chancery; if that was already its status in 1396 (and this is not wholly certain), he is the only serjeant known to have been called from such an inn. He may also have another (and in the present context more significant) distinction: that of being the only Irishman who became a serjeant of the Westminster bench during the late middle ages.

The only other possibly Irish serjeant is Skrene's near contemporary, William Rickhill. Rickhill became a serjeant in England in 1383, was a king's serjeant from 1383 to 1389 , and ended his career as a puisne justice of the common bench in England between 1389 and 1407. It was Sir Edward Coke who seems to have been the first to have asserted (but without any supporting evidence) that Rickhill 'was an Irishman borne', ${ }^{72}$ and in that assertion he has been followed by others. ${ }^{73}$ Rickhill certainly did have some Irish connexions. In 1379 and again in 1380 he acted as one of the general attorneys of the earl of Ormond while the earl was in Ireland ${ }^{74}$ and William Skrene (the one indubitably Irish serjeant) can be found acting (in 1393) as one of his feoffees when he acquired the Cambridgeshire manor of Wood Ditton ${ }^{75}$ and later as one of his executors. ${ }^{76}$ These connexions are not, however, enough to prove that Rickhill came from Ireland and his will (which

${ }^{72}$ Edward Coke, The first part of the Institutes of the laws of England (5th ed., London, 1656), p. 377b.

${ }^{73}$ Edward Foss, The judges of England, 1066-1864 (9 vols, London, 1848-64), iv, $174-6 ; D . N . B$. entry.

${ }^{74}$ Cal. pat. rolls, $1377-81$, pp $381,547$.

${ }^{75}$ Ibid., $1391-6$, p. 300 . Skrene seems also in effect to have stood surety for the payment of part or all of the purchase price (Cal. close rolls, 1392-6, p. 222).

${ }^{76}$ Cal. close rolls, $1405-9$, p. 504. 
was copied in full into the register of Archbishop Arundel) shows not the smallest trace of any Irish connexion. ${ }^{77}$ If he was of Irish origin, by the time of his death he had either forgotten or no longer wished to remember that fact.

The Anglo-Irish were certainly coming to England as law students for a period of almost two centuries before 1485 , and it is possible from a variety of sources to name some (though probably only a relatively small proportion) of those who came. London and Westminster probably established themselves even before the creation of the Inns of Court as the places for advanced study of the common law, and the creation of permanent institutions offering advanced legal education (the Inns of Court) may simply have consolidated an existing tradition of Irishmen who sought such an education coming to London to receive it. Although there is some evidence from the fifteenth century to suggest that individual inns may for periods have banned Irish fellows (and perhaps also Irish students) for reasons which may have been institutional in nature, such bans were never more than temporary, and the Irish branch of the Anglo-Irish legal profession never seems to have found it necessary to establish its own advanced educational institutions in Ireland, and may have been too small to do this anyway. Irish lawyers also certainly came to England during the same period for Irish litigation before English courts, either on behalf of their clients or on their own behalf, though I have not been able to trace this beyond the early years of the fourteenth century. Perhaps surprisingly (given the common educational system), there is very little evidence of Irish lawyers settling in England: the one certain example of William Skrene shows that it could be done, and William Rickhill may provide a second example. Otherwise there is nothing. Perhaps prospects were better in Ireland. Perhaps it was genuinely difficult (and took exceptional abilities) for an Irish lawyer (even of English extraction) to succeed in the mother country. It may even be that they simply preferred living in Ireland. 